\title{
Criticism and Society: The Birth of the Modern Critical Subject in China
}

\section{Q. S. Tong and Xiaoyi Zhou}

Over the past ten years or so, there have been repeated calls in China for the creation and establishment of a system of critical theory that bears distinct indigenous features, a system that is "national," or "Chinese," and that will therefore be different, both formally and substantively, from those imported critical approaches and theoretical formulations. ${ }^{1}$ However, these

We thank Paul Bové, Jonathan Arac, and the anonymous readers of the boundary 2 editorial collective for their comments and suggestions. We also owe Meg Havran a note of thanks for editing the manuscript. Translations from Chinese sources, unless otherwise noted, are ours.

1. Articulations of the desire for an indigenous critical theory are copious. They started to be heard in the late 1980s and became a visible critical movement in the mid-1990s. In the first issue of Wenxue pinglun (Literary review) in 1997, the leading critical journal in China, for example, an entire section is devoted to the issue of how to modernize classical Chinese critical theory. The following list of titles, albeit short and far from complete, is perhaps sufficient to show the solemnity and intensity of the issue for Chinese literary intellectuals: Cao Shunqing, "Ershiyi shiji zhongguo wenhua fazhanzhanlue yu chongjian zhongguo wenlun huayu" (Strategies for Chinese cultural developments in the twenty-first century and reconstruction of the discourse of Chinese literary theory), Dongfang congkan (Oriental series), no. 3 (1995); Qian Zhongwen, "Huidanglinjueding: huimou ershishiji boundary 2 29:1, 2002. Copyright @ 2002 by Duke University Press. 
"Chinese features" have never been fully defined, although indigenous critical resources and historical forms of critical knowledge are the most obvious source of inspiration for this movement. To some extent, these calls may be taken as an expression of a visible intellectual fatigue resulting from the overwhelming presence of crude reproductions and, in some cases, blatant distortions of Euramerican critical theories in China. More importantly, bemoaning the loss of the classical system of critical knowledge, they register, at the same time, an intellectual resistance, conscious or otherwise, to Western critical theories. These calls, in order to be taken seriously, need to rise above the level of mere rhetoric of nostalgia and resistance. Critical inquiry into the question of whether it is possible to have a localized system of critical theory requires, in the first place, an informed understanding of the conditions under which modern Chinese criticism came into being. Regardless of the nationalistic undertones of these calls, one may argue that they challenge the fundamental premises of discursive critical practices in China since the May Fourth period. The present state of critical theory and its future development need to be contemplated in relation to its predecessor-modern criticism -in China's critical genealogy. In the post-Mao era, China has witnessed yet another wave of Western thought, including movements of critical thought similar to that during the May Fourth period. In the following, by revisiting the moment that modern critical consciousness was formed in the early twentieth century, we attempt to give historical, social, and intellectual specificities to the emergence of modern Chinese criticism and thereby to offer some thoughts on the question of whether it is possible to establish a Chinese system of critical knowledge under the present condition.

\section{Shihua and Chinese Critical Tradition}

The study of the formation of a modern critical consciousness in China has to begin with a tragic moment in the intellectual history of China,

wenxuelilun" (Reaching the peak and looking back at literary theories in the twentieth century), Wenxue pinglun, no. 1 (1996); Chen Hong and Shen Liyan, "Yetan zhongguo wenlun de 'shiyu' yu 'huayuchongjian'" (Some thoughts on the "aphasia" of Chinese literary theory and its "discursive reconstruction"), Wenxue pinglun, no. 3 (1997); Cao Shunqing and Li Siqu, "Zailun chongjian zhongguo wenlunhuayu (More on the reconstructing of the discourse of Chinese literary theory), Wenxue pinglun, no. 4 (1997); Zhang Haiming, "Gudai wenlun he xiandai wenlun" (Classical literary theory and modern literary theory), Wenxue pinglun, no. 1 (1998); and Qian Zhongwen, "Wenxuelilun xiandaixing wenti" (The problem of the modernity of literary theory), Wenxue pinglun, no. 2 (1999). 
a moment that, for us, both symbolizes and evidences the pain and violence China experienced in the process of inventing its modern literary identity in the early twentieth century. The tragedy took place at the Summer Palace, the famous but ominous imperial summer resort in Beijing, in the summer of 1927. Wang Guowei, a preeminent scholar, a quintessential Chinese man of letters, and arguably the first modern Chinese critic who consciously incorporated into his critical repertoire Western philosophical and aesthetic formulations, committed suicide by throwing himself into the Kunming Lake. He was fifty years old at the time and left behind a wealth of critical and scholarly work, as well as the enigma of his suicide. ${ }^{2}$ Why did he decide to conclude his life in such a violent manner? Why did he, a scholar celebrated at the time and beyond for his monumental work, his intellectual brilliance, his poetic creativity, and his critical acumen, decide to terminate his life and career so abruptly?

Wang Guowei is an enigma not just because of the unknown, and perhaps unknowable, motive for his suicide but also because his critical work, taken as a whole, reveals a remarkable methodological ambiguity and instability. His critical study of the classical Chinese novel $A$ Dream of the Red Chamber, for example, is considered by many to be the first accomplished piece of modern critical writing in China, employing Western philosophical and aesthetic categories and concepts, notably those of Schopenhauer, in the reading of this Chinese novel. ${ }^{3}$ At the time of its publication in

2. After his death, a written statement by Wang was discovered. He was deliberately vague and evasive about the cause of his suicide, but the opening lines are suggestive: "The only thing missing in my life of fifty years is death. Having experienced all these changes, I'm determined not to be humiliated any more." See Wang Guowei zhisi (Death of Wang Guowei), ed. Luo Jizhu (Taipei: Qiling chubanshe, 1995), 7. Although scholars remain uncertain about the cause(s) of Wang's suicide, one widely accepted view is that his decision resulted from a number of frustrations, a major one being his inability and failure to reconcile the Chinese system of knowledge and its Western counterpart. Wang Guowei, even though a rare genius in traditional scholarship, could not, we are told, get to the truth of "the life of Chinese culture" and could not grasp the nature of Western culture. "He could not see the future of his life and the future of the life of Chinese culture, and he was so depressed that he ended all this by taking his own life" (Mo Zongsan, Wushi zishu [A selfportrait at the age of fifty] [Taipei: Erhu chubanshe, 1989], 26).

3. Wang's early interest in German philosophy is of particular relevance here. According to his own account, he started reading Kant's Critique of Pure Reason in early 1903 but found it daunting and turned to Schopenhauer. From the summer of 1903 onward, Schopenhauer's books became his daily companion. "I derived," he tells us, "particular pleasure from his epistemology, which enabled me to look back at Kant's theory. His philosophy of life, his precise and insightful observations and his accurate discussions and comments were also instructive and delightful." Despite his admiration for Schopenhauer, 
1904, the article surprised some and bewildered others, precisely because it was a pathbreaking work that brought to the attention of the Chinese scholarly community the possibility, and the appeal, of a new critical paradigm. However, only a few years later, Wang produced, in 1908, his treatise on Chinese poetics, arguably the finest example of his critical writing, Renjian cihua (Talks on ci poetry in the human world), in a style typical and exemplary of traditional Chinese poetic criticism. In terms of the scope of its critical concerns and its mode of articulation, Wang's Talks presents a striking contrast to his earlier critical method embodied in "On A Dream of the Red Chamber," reconfirming, as it were, his renewed commitment to the indigenous literary and cultural resources in general and to the classical mode of critical practice in particular.

By "the classical mode of critical practice," we do not mean a conceptual category that may be evoked conveniently to foreground the significance of modern critical practice. We refer, rather, to the specific mode of critical practice, shihua or cihua (talks on shi or ci poetry), of which Wang's Talks on Ci Poetry in the Human World is exemplary. ${ }^{4}$ The term shihua was first used by Ouyang Xiu (1007-1072) in his collection of critical comments entitled Liuyi shihua (Liuyi's talks on poetry). Shihua has since flourished, making up the backbone of the classical critical establishment in China. Its self-defined function is to "determine meanings of sentences, set down things ancient and contemporary [related to poetry], report great virtues, record extraordinary and bizarre events, and amend errors." ${ }^{5}$ Shihua, therefore, is mainly concerned with textual commentaries, takes a special interest

however, Wang later developed visible reservations about him. Half of Schopenhauer's theory, Wang continues, "is a product of his own subjectivity, and is not objective knowledge." Wang Guowei, "Zixu, Jingan wenji" (Preface to collected writings of Wang Guowei), in Wang Guowei wenji (Collected writings of Wang Guowei), ed. Yao Ganming and Wang Yan (Beijing: Zhongguo wenshi chubanshe, 1997), 3:469. For a detailed study of Wang's ambivalence about Schopenhauer and German aesthetics in general, see Wang Youxing, Xuanze, jieshou yu shuli (Choosing, receiving, and distancing) (Beijing: Joint Publications, 1999).

4. In the Chinese classical tradition of versification, shi and ci are two major forms of vigorously controlled and regulated poetry. Shihua takes shi poetry as its subject, and cihua, ci poetry. As there is no substantive difference between shihua and cihua, shihua will be used hereafter as a generic term to refer to this mode of criticism. Although there have been individual works of criticism before the Song period, notably, for example, Liu Xie's Wenxin diaolong (Literary mind carves dragons), shihua is the most prominent form of critical practice and is therefore most representative of classical criticism.

5. Xu Yi, Yanzhou shihua, in Zhongguo lidai shihuaxuan (Anthology of Chinese shihua), ed. Wang Dapeng, Zhang Dakun et al. (Changsha: Yuelu shushe, 1985), 2:402. 
in the close reading of poetic lines or phrases, and derives much pleasure from discovering, collecting, and disseminating literary curiosities.

Formulated and presented in textual fragments, shihua is marked by excessive economy of verbal expression. Most typically, it assembles a series of textual fragments - notes, observations, thoughts, or anecdotesthat, seemingly jotted down in a casual manner, are not, and are not meant to be, related to one another structurally or thematically. Freestanding and isolated, these fragments in a work of shihua may comprise only one or two sentences and are not usually longer than one page. Shihua makes no attempt to advance a consistent thesis or structured argument that may marshal textual fragments into some form of coherence and enjoys its own thematic fragmentation and formal disunity. Rather than analytic and systematic, shihua, therefore, tends to be fuzzy, cryptic, elliptic, impressionistic, and often rather sensuous in presentation. This is also true of Wang Guowei's Talks, which is sometimes "maddeningly terse," even though his comments and observations, for scholars and critics, "form a consistent pattern." 6 The following is one of the most famous fragments from Wang's Talks:

Throughout the ages, all those who have been highly successful in great ventures and in the pursuit of learning must of necessity have [successively] experienced three kinds of jingjie [state or stage]. "Last night the West wind shrivelled the green-clad trees, / Alone I climb the high tower / To gaze my fill along the road to the horizon." This is the first state. "My clothes grow daily more loose, yet care I not. / For you am I thus wasting away in sorrow and pain." This is the second state. "I sought her in the crowd a hundred, a thousand times. / Suddenly with a turn of the head, / That one there where the lamplight was fading." This is the third state. Such words as these could not have been uttered by other than the great ci poets. However, if we happened to use this idea [of jingjie] to explain the meaning of the poems themselves, I am afraid Yan Shu, Ouyang Xiu, and Xin Qiji would have demurred. ${ }^{7}$

This is by no means the most cryptic of the critical fragments collected in Talks. What Wang attempts to describe here is the process of intellectual

6. Adele Austin Rickett, Wang Kuo-wei's “Jen-chien Tz'u-hua”: A Study in Chinese Literary Criticism (Hong Kong: Hong Kong University Press, 1977), x.

7. Rickett, Wang Kuo-wei's "Jen-chien Tz'u-hua”, 50. For the sake of clarity, we have slightly modified Rickett's translation and have inserted additional punctuation marks. 
development, in which a traditional Chinese poet or critic, or a man of letters more generally, through unfailing diligence, reaches the realm of intellectual freedom and is finally able to discover or achieve, almost effortlessly and spontaneously, what has been desired from the very outset. This process, for Wang, characterizes the production of great literary or scholarly works. If it is understood to be Wang's view on the creative process of poetic production, one may be tempted to compare this fragment with Wordsworth's famous statement that poetic spontaneity originates from profound thinking in emotional tranquility. ${ }^{8}$ However, that Wang cites the ci passages by the three poets mentioned in the fragment-Yan Shu, Ouyang Xiu, and Xin Qiji-and employs poetic imagery rather than a theorized critical language as Wordsworth does, reveals, perhaps more than anything else, that shihua is conscious of its critical identity and its unique mode of articulation.

Gnomic style of articulation and fragmentary expression are not uniquely Chinese, of course. Notes and marginalia are, for example, Coleridge's favorite forms of articulation. We may also think here of Friedrich von Schlegel's and Nietzsche's philosophical fragments and aphorisms. But it should be emphasized that shihua is not merely a personalized style of writing but rather an established form of critical expression and a highly professionalized mode of critical knowledge production. Shihua, in other words, is not a collection of casual remarks and comments on poetry; it is a critical topos, a genre, and a constituted form of critical articulation between the Song period and the end of the nineteenth century. It is only through intuitive sympathy and the kind of Joycean intellectual epiphany, which would require many years of training in poetry and poetic criticism to experience, that one can fully comprehend the fragmentary obscurity of shihua and derive pleasure from it. ${ }^{9}$

In the discourse of traditional criticism, shihua is by far the most im-

8. Wordsworth, in "Preface" (1850) to Lyrical Ballads, describes this process thus: "Good poetry is the spontaneous overflow of powerful feelings: it takes its origin from emotion recollected in tranquillity: the emotion is contemplated till, by a species of re-action, the tranquillity gradually disappears, and an emotion, kindred to that which was before the subject of contemplation, is gradually produced, and does itself actually exist in the mind." See William Wordsworth: Selected Prose, ed. John O. Hayden (Harmondsworth: Penguin Books, 1988), 297-98.

9. James Joyce, in Stephen Hero, defines epiphany as "a sudden spiritual manifestation, whether in the vulgarity of speech or of gesture or in a memorable phase of the mind itself. ... [It] was for the man of letters to record these epiphanies with extreme care," and these epiphanies "are the most delicate and evanescent of moments." See James Joyce, Stephen Hero, ed. Theodore Spencer (London: Paladin, 1991), 216. 
portant and most widely practiced form, and criticism of narrative fiction, which also frequently employs the fragmentary mode of expression, is relatively marginal and not comparable to shihua either in quantity or in quality. To a great extent, classical Chinese criticism finds its clearest and most concentrated expression, and in that sense is embodied, in shihua, at least since the Song period. It is then possible, and indeed necessary, to identify some of its most salient features. Chinese criticism, as Wen Rumin observes, "mostly employs loose and free forms of expression such as shihua, cihua, or notes on narrative fiction, favors intuition and experience, often valorizes artwork on the basis of impression or epiphanic understanding. Using laconic poetic language, it reveals and transmits the spirit of artwork or [the critic's] understanding." Classical Chinese criticism, therefore, is not concerned with "abstract analysis or logical enunciation and does not have recourse to theoretical systematism. [It] does not rely on established frameworks or criteria, but on the literati's shared habit of thinking and their identical aesthetic proclivities ... and on their similar taste and standard of judgment." 10

Traditional Chinese criticism, then, is not a conceptualized category or an abstract notion but rather a mass of critical knowledge accumulated over hundreds of years and made available as a collective formation. It is with reference to the discursive practices of classical criticism that Wang's "On A Dream of the Red Chamber" has been considered a monumental development in the history of modern Chinese criticism. It represents a conscious break, in terms of both its form and its critical concerns, from the mainstream critical practice embodied in shihua and signifies the advent of a new critical paradigm, the significance of which had yet to be fully comprehended and recognized at the time of its publication. Despite its linguistic archaism, this essay bears some of the features of modern critical writing as we know it. Although we are not concerned here with his readings of the novel, some of which are controversial, it is worthwhile to outline its structure to illustrate how it differs from shihua. The essay consists of four sections, the first of which is an abstract discussion of art as a sublimation of life, "Concepts of Life and Art." This is followed by an analysis of the literary motifs of the novel, "The Spirit of $A$ Dream of the Red Chamber." Sections 3 and 4 are entitled "Aesthetic Values of $A$ Dream of the Red Chamber" and "Ethical Values of $A$ Dream of the Red Chamber," respectively. The essay

10. Wen Rumin, Zhongguo xiandai wenxue pipingshi (History of modern Chinese literary criticism) (Beijing: Beijing University Press, 1993), 3. 
ends with an afterword, a substantial part of which is an extended quotation from Schopenhauer's The World as Will and Representation."

It is evident that this essay follows a critical logic and methodology visibly different from shihua. The differences between this essay and Wang's Talks are remarkable, not just because the former draws on intellectual and critical resources from outside the indigenous systems of knowledge but also because it presents a new critical horizon hitherto unknown in China. At the time of its publication, it was regarded as an "eccentric piece" that did not seem to fall into any existing framework of critical articulation. In the history of Chinese literary criticism, "there had not been any critical studies that so systematically applied philosophical and aesthetic theories to a literary work." Eccentric as it was, the article, we are told, "compelled people to think: criticism can be indeed practiced differently; and should traditional criticism also broaden its own horizon?"12

Questions of this kind, inspired by the methodological novelty of Wang's essay, may be viewed, as well, as a manifestation of an emergent skepticism about the normality and legitimacy of shihua. It is therefore perhaps profoundly ironic and paradoxical that Wang, after the completion of this essay, returned to the shihua mode of criticism, and that his Talks on Ci Poetry in the Human World, although not completely free from Schopenhauer's influence, seems to have resituated him in the discourse of classical literary criticism. Brilliant as it is, however, Wang's Talks constitutes a conclusion to the tradition of shihua, which, as a critical norm and constituted mode of critical practice, has since disappeared into historical oblivion and has never been discursively practiced again. ${ }^{13}$

11. See Wang Guowei, "On A Dream of the Red Chamber," in Collected Writings of Wang Guowei, 1:1-23.

12. Wen Rumin, History of Modern Chinese Literary Criticism, 4.

13. This is not to say, of course, that shihua or critical fragments as a personalized form of critical articulation have been totally abolished. As other decentralized or dethroned traditional cultural formations in China, it continued to influence some critics and scholars after Wang Guowei. Kuang Zhouyi's Huifeng cihua (Huifeng's talks on ci poetry), for example, was published in 1936, though it was written at least a decade before its publication (he died in 1926). Qian Zhongshu's celebrated Guan Zhui Bian (Collections of pipe awl) (1979) is another notable exception, which, however, can hardly be considered a piece of shihua or a piece of critical work for that matter. Its employment of the fragmentary mode of articulation creates, and is perhaps driven by, a self-consciousness of its own uniqueness. This, for us, ironically testifies to the fact that fragments are no longer the norm or constituted mode of articulation that must be followed in the production of criticism. Qian has never produced a piece of work in the genre of shihua. 


\section{The Ideology of shihua}

The disappearance of shihua as a critical establishment in the first decade of the twentieth century is not a historical accident. Some of the formal features of shihua, briefly described above, are not just formal; they are manifestations of a critical attitude and a class (un)consciousness that define it as increasingly inadequate to fulfill its own intellectual and social expectations under the new historical conditions. Shihua is ostensibly esoteric. Esoteric is a familiar term in contemporary metacritical discourse and is often used to register critical theory's own discontent about its formulations that are jargon-ridden and unnecessarily obscure. The term is used here, however, not merely to indicate the kind of difficulties in approaching shihua fragments, such as Wang's passage quoted earlier. Shihua is not just esoteric; it is meant to be esoteric.

Functioning in an exclusive literary coterie, the traditional Chinese critic was often self-positioned as a member of a unique and privileged social group. This is not only because, following Chinese tradition, a critic was often a poet, and a poet was often a government official at the same time. As is well known, the selection of officials in China was completed through the process of an elaborate system of imperial examinations. "In these examinations proficiency in the writing of poetry and essays counted heavily." Generally speaking, though with some exceptions, "the poets of China have all been, first of all, officials . . . and their goal was to pass the examinations which would assure them a post in the government." ${ }^{14}$ This official-poet-critic trinity in the post-Song period explains the ideological commitment of shihua and defines the social positioning of its author. The pervasive consciousness of the critic's own elitist status not only produced the classical critical subject that is closely identified with one particular social group but also confined critial practice to that social group only.

Shihua, therefore, was produced for those who belonged to the same intellectual elite. Its gnomic utterances, its cryptic formulations, and its preoccupation with the aesthetic all suggest that it is a form of literary writing that is meant for a carefully selected readership. Critics and poets "formed, by the very nature of their position, an elite body of educated men, capable of talking intelligently to each other on scholarly and literary subjects. It was

14. Adele Rickett, "The Personality of the Chinese Critic," in The Personality of the Critic, ed. Joseph P. Strelka (University Park: The Pennsylvania State University Press, 1973), 113. 
very natural for them to want to criticize and encourage each other." ${ }^{15}$ The implied readership of shihua, to a great extent, determined the form of its articulation. There was the widespread assumption "on the part of a Chinese critic," almost as a matter of convention, that "his reader knows what is in his mind and that a few words are therefore all that are needed to enlighten that reader." ${ }^{16}$ There was, then, a preestablished trust, a tacit agreement, a hermeneutic contract, so to speak, concerning the discursive relationship between critic and reader. Speaking of the psychology of Chinese criticism, Hsia Tsi-an observes, with humor and irony: "In general, Chinese works of literary criticism have been written for sharp-witted men to read. With one point made, all becomes immediately clear with no need to waste words. Western critical essays, on the other hand, have been written for the dullwitted and so there is a need to explain clearly the principles involved." ${ }^{17}$

Shihua was a privileged locale of value, and its influence, if any, remained within a small intellectual community. The circulation of critical knowledge did not travel very far beyond the social space in which the critic was positioned and was thus firmly situated in a private space. Elitist, detached, and conservative, the Chinese poet-critic was a private individual; and working within a private space, he was also an isolated and alienated individual and had no sense of collective responsibility or communal vision. Social concerns and political interventions were not on his agenda, nor was he interested in creating a public arena of possibilities and alternatives. Shihua, confined to the realm of the aesthetic, is thus never a public formation but, to use Pierre Bourdieu's words when he broaches the issue of the "historical genesis of the pure aesthetics," involves an "active forgetting of the history that has produced it" and is "the product of privilege." ${ }^{18}$ Shihua, as a general formation, could readily degenerate into a discourse of triviality, banality, and sterility. It is, then, no surprise that there were remarks and comments highly critical of shihua throughout history, even though it was the canonized form of critical writing in China before the twentieth century. ${ }^{19}$

15. Rickett, "The Personality of the Chinese Critic," 113.

16. Rickett, Wang Kuo-wei's “Jen-chien Tz'u-hua," ix.

17. Quoted in Rickett, Wang Kuo-wei's “Jen-chien Tz'u-hua," ix.

18. Pierre Bourdieu, The Rules of Art: Genesis and Structure of the Literary Field, trans. Susan Emanuel (Stanford, Calif.: Stanford University Press, 1992), 285, 288, 289.

19. Huang Yongcun, for example, said in 1169: "Many [shihua] and miscellaneous notes have been produced, but usually they only contribute to the enjoyment of light conversation, and are hardly beneficial to the younger generation." Zhang Xuecheng (1738-1801) "charged [shihua] with corrupting morals and accused [shihua] writers of "participating in 
The classical style of criticism differs most radically from modern criticism in the critic's own consciousness of himself as a member of an elite social group and the positioning of shihua as above the taste of the common reader. Rather than reaching out to the general public as, for example, eighteenth-century English criticism did, it is exclusive at all levels-social, political, and intellectual. Its private nature is defined by its form of articulation and its mode of circulation. In the early twentieth century, this form of critical practice was increasingly irrelevant in China, as it was so consciously detached from the social conditions that were soon to become major concerns of the intellectuals during the May Fourth period..$^{20}$ The transformation from traditional poetics to modern criticism is, then, necessarily, a process in which the critic must be relocated from a private realm to a public one, from the realm of aesthetics to the realm of action, a process in which the critic must be transmuted into a modern public intellectual. This historical transformation bears a remarkable resemblance to the process by which modern criticism emerged as a form of intellectual practice in the West in the early eighteenth century.

\section{Criticism and Modernity}

While critical practice in the West can be traced back as early as ancient Greece, it is now generally agreed that modern discursive critical

the common practice of following the trend and craving fame by means of teachings which are inadequate for establishing a school of thought, and writing down whatever they intend to say with no more style than anyone else uses." Yuan Mei (1716-1798) was most explicitly critical of its structural fragmentation and its thematic triviality: "Since the [Song] dynasty, men of letters have been fond of writing [shihua]. Among these talks on poetry, sixty to seventy percent are disorganized and trivial." See Hsu Hsiao-ching, "Talks on Poetry as a Form of Sung Literary Criticism" (Ph.D. diss., University of Wisconsin, Madison, 1980), 2-3.

20. The May Fourth movement derived its label from the students' demonstration on 4 May 1919, which was sparked by the decision at the Versailles Peace Conference that Japan should retain defeated Germany's rights and possessions in Shandong. It is generally agreed that the most significant years of the movement were between 1917 and 1921, with the students' demonstrations as a moment that divided the May Fourth period into two phases. The May Fourth intellectuals were preoccupied with spreading Western Enlightenment ideas in the first phase, but began to carry the movement "beyond purely intellectual circles" by launching "an all-out attack on tradition and conservatism" in the second phase. See Chow Tse-Tsung, The May 4th Movement: Intellectual Revolution in Modern China (Cambridge: Harvard University Press, 1960), 6. 
practice has its historical roots in the early Western experience of modernity. Bourgeois intellectual liberalism in the eighteenth century constituted a necessary condition under which new forms of literary production were invented. Like the modern novel, which has long been considered an invention of the bourgeois creative imagination, modern literary criticism, different from the poetics and rhetoric prevalent before the eighteenth century, is, in its origin, a bourgeois form of intellectual articulation. ${ }^{21}$ As the rise of the modern novel responded to the increasing popular interest in the genre, modern criticism responded to the growing intellectual desire to participate in social and public affairs and reached out to the general reading public. In contrast to the earlier form of literary discussion, which was confined mainly to aristocratic society, "the modern concept of literary criticism," seen historically, as Peter Hohendahl observes, "is closely tied to the rise of the liberal, bourgeois public sphere in the early eighteenth century. Literature served the emancipation movement of the middle class as an instrument to gain self-esteem and to articulate its human demands against the absolutist state and a hierarchical society. Literary discussion, which had previously served as a form of legitimation of court society in the aristocratic salons, became an arena to pave the way for political discussion in the middle classes." 22 Within such a critical discourse, critics positioned themselves as public intellectuals operating in a newly formed public sphere and were intimately engaged with contemporary social and political issues. Apart from the responsibility of educating the bourgeois sense and sensibility, criticism, discursively practiced, carved out and consolidated a liberal public space that was needed to promote its social visibility and the social positioning of its practitioners.

Modern literary criticism, as a genre, as a discursive practice, as a mode of social intervention, was a bourgeois invention that was socially and politically inspired and motivated. Its primary task was to democratize taste

21. This is not to say that there was no narrative fiction before the rise of the modern novel or that the modern novel drew on no earlier literary resources. Arnold Kettle considered the medieval romance and courtly novels of Italy and France, among other forms of narrative writing, as the main sources of the modern novel, but he argues that the English novel "dates from the eighteenth century." See Arnold Kettle, An Introduction to the English Novel (London: Hutchinson University Library, 1950), 1:25. For a discussion of the discursive formation of modern criticism in England, see Terry Eagleton, The Function of Criticism: From "The Spectator" to Post-structuralism (London: Verso, 1984).

22. Peter Uwe Hohendahl, The Institution of Criticism (Ithaca, N.Y.: Cornell University Press, 1982), 52. 
and emancipate literary experience from the socially privileged. The emergence of the new urban reading public, therefore, was crucial for the understanding of the conditions under which modern criticism became a major form of articulation. As Jürgen Habermas observes, "The court aristocracy of the seventeenth century was not really a reading public. To be sure, it kept men of letters as it kept servants, but literary production based on patronage was more a matter of a kind of conspicuous consumption than of serious reading by an interested public. The latter arose only in the first decades of the eighteenth century." 23 "The court's claim to cultural leadership was first shaken when bourgeois critics were able to appeal to the taste of the public." 24 In England, for example, Joseph Addison's advocacy of "the taste of town" was manifestly aimed at the urban reading public, conceding "more authority to the approval of the public than to the rigid critics, who only judge according to rules." ${ }^{25}$ Published and circulated in an early version of the mass media, such as The Spectator in England, modern criticism, therefore, embodied a politics that foregrounded its social function, contributed substantially to the formation of a bourgeois public sphere, and as such constituted a significant dimension of the Western experience of modernity.

To attribute the rise of modern critical practice to the early bourgeois intellectual liberalism and the formation of a liberal public sphere is to determine its ideological provenance, to specify, historically, the social and political conditions under which modern criticism in the West became a major form of bourgeois intellectual articulation and practice, and to situate criticism within the discourse of Enlightenment values. Reason, good sense, and scientific thinking, for example, are some of the most enduring values that modern criticism embraces and practices. Embracing and advocating same or similar values, the May Fourth intellectuals were engaged in a project to create the new critical subject, which was a constitutive part of the larger project of reforming and modernizing China. The birth of modern Chinese critical practice in the early twentieth century, at the cost of the classical mode of critical practice, was coeval with the formation of a modern Chinese consciousness as a whole.

23. Jürgen Habermas, The Structural Transformation of the Public Sphere: An Inquiry into a Category of Bourgeois Society, trans. Thomas Burger (Cambridge: MIT Press, 1995), 38. 24. Klaus L. Berghahn, "From Classicist to Classical Literary Criticism, 1730-1806," in $A$ History of German Literary Criticism, 1730-1980, ed. Peter Uwe Hohendahl (Lincoln: University of Nebraska Press, 1988), 40.

25. Berghahn, "From Classicist to Classical Literary Criticism, 1730-1806," 41. 


\section{Binarism as Imaginary and Strategy}

Under the present intellectual and critical conditions, especially after the publication of Edward Said's Orientalism in 1978, it is almost an embarrassment to resort to binary opposites such as the traditional and the modern in critical inquiry. However, in delineating the historical process of transformation in China in the early twentieth century, one needs to return to the intellectual ethos of the time in order to fully appreciate the radicalness of the May Fourth intellectuals. For them, such binaries as the traditional and the modern were diametrically opposed, and the perceived differences between China and the West were widely employed as a point of departure. Even Wang Guowei, who was by no means a member of the radical intellectual group at the time, sweepingly generalized, and at the same time essentialized, what he saw as the differences between China and the West and compared them in terms of an overt and crude binarism:

It is characteristic of our nation to be pragmatic and simple. The characteristics of Westerners are speculative and scientific, good at abstraction and classification, applying the two methods-generalization and specification - to all things in the world, visible or shapeless.... What we Chinese are good at is practice ... we are satisfied with empirical knowledge. Unless forced by necessity, we never study fully the method of classification. . . . Therefore, there is argumentation but no logic in China, there is literature but no grammar. This is sufficient to show that abstraction and classification are not what we are good at. China's scholarship has not yet reached the level of self-consciousness. ${ }^{26}$

Comparisons of this kind between China and the West were prevalent in the early twentieth century. It is worth noting here that Wang considers the absence of Western-style prescriptive grammar in classical Chinese writing a major defect of Chinese literature, and, as we shall see later, Hu Shi argues for the importance of grammar in the production of a new literature. The absence of Western-style prescriptive grammar in China before the twentieth century may be considered an indication that the Chinese language was perhaps not particularly conscious of its own mechanism of signification at a metalinguistic level. ${ }^{27}$ The notion that the Chinese language had

26. Wang Guowei, "Lun xinxueyu zhi shuru" (On the importing of new concepts and terms), in Collected Writings of Wang Guowei, 3:40-41.

27. The first Chinese grammar book written by a Chinese was Mashi wentong (Ma's gram- 
no grammar was first established in the discourse of European comparative philology in the nineteenth century. ${ }^{28}$ This is just one example of how some Chinese intellectuals, in the first few decades of the twentieth century, were influenced by the modern Western system of knowledge in their scrutiny of traditional Chinese cultural formations and practices. For them, the lack of formulated grammatical rules in Chinese writing testified to the absence of a more significant aspect in the Chinese way of thinking. Grammar was considered not merely a set of rules governing the use of language but, as John Stuart Mill, for example, writes, "the most elementary part of logic ... the beginning of the analysis of the thinking process." ${ }^{29} \mathrm{It}$ is evident that for Wang, the differences between the Chinese mind and its Western counterpart, in regard to the ways they work, are not just perceivable but substantive. Wang, of course, was not the only one to ponder the incommensurabilities between China and the West in terms of not just research methodologies or ways of thinking but a whole range of aspects of human experience. As indicated, it was a pervasive practice during, and indeed beyond, the May Fourth period to situate China and the West in a binary relationship; and comparisons and contrasts between them, formulated and presented in the most general of terms, were never so much a problem for the May Fourth intellectuals as they are for us today.

Comparisons of this kind, however, inevitably invite questions about the validity of the basis on which they are conducted. In order to perform comparative studies, such notions as "modern" and "traditional" have to be ontologized as if they were categories solidified throughout history and immune to change, and the complexities of cultural practices are thus reduced to an oversimplified set of opposites. While perceived differences can assist thinking, the mistake here, to use Raymond Williams's words, "is in taking terms of analysis as terms of substance." 30 In fact, "tradition," as it is now

mar), published in 1898. Almost a century earlier, however, Joshua Marshman had produced his Elements of Chinese Grammar (1814). We are grateful to Kingsley Bolton for the reference and for his help in other ways.

28. For a useful discussion of how Chinese was seen and understood as having no grammar, see Haun Saussy, "Always Multiple Translation, or, How the Chinese Language Lost Its Grammar," in Tokens of Exchange: The Problem of Translation in Global Circulation, ed. Lydia H. Liu (Durham, N.C.: Duke University Press, 1999), 107-23.

29. John Stuart Mill, "Inaugural Address Delivered to the University of St. Andrews (1867)," in Essays on Equality, Law, and Education, ed. John M. Robson (London: Routledge and Kegan Paul, 1984), 228.

30. Raymond Williams, Marxism and Literature (Oxford: Oxford University Press, 1977), 129. 
understood, is not an indigenous concept, and there was no word in Chinese for the idea of tradition that, as defined by T.S. Eliot, encompasses the sense of "the pastness" as well as that of "its presence." ${ }^{31}$ And chuantong, the modern Chinese term for tradition, "while Chinese in origin, came back to China from Japan as a neologism." ${ }^{2}$

"Tradition," whether as a conceptual category or an imaginary, provided an occasion and a possibility for the May Fourth intellectuals to launch their project of modernizing China. Under the sway of instrumental Reason, they had no patience to ponder these concepts as academic ones. For example, Yan Fu, who, like Wang Guowei, was not a member of the radical intellectual group, expressed well the kind of intellectual pragmatism at the time: "We have no time to ask whether this knowledge is Chinese or Western, whether it is new or old. If one course leads to ignorance and thus to poverty and weakness ... we must cast it aside, if another course is effective in overcoming ignorance and thus leads to the cure of our poverty and weakness we must imitate it even if it proceeds from barbarians." ${ }^{33}$ However fluid and unstable it may be, "Chinese tradition" was generally perceived as an obstacle to China's progress to modernity. The modernization project must then start with an erasure of historical memories and a destruction of the tradition that, as many saw it at the time, was inscribed, legitimated, and constituted in discursive forms of cultural production. The May Fourth cultural movement was, above all, a titanic struggle to create, in the cultural realm at least, a modern identity for China on the ruins of the past. Therefore, like Roland Barthes's Japan that has afforded him "a situation of writ-

31. T.S. Eliot, in "Tradition and the Individual Talent," defines tradition in relation to the sense of history thus: "It involves, in the first place, the historical sense . . . and the historical sense involves a perception, not only of the pastness of the past, but of its presence.... This historical sense, which is a sense of the timeless as well as of the temporal and of the timeless and of the temporal together, is what makes a writer traditional." See Selected Prose of T.S. Eliot, ed. Frank Kermode (New York: Harcourt Brace Jovanovich, 1975), 38. 32. Benjamin Schwartz, "The Limits of 'Tradition Versus Modernity' as Categories of Explanation: The Case of the Chinese Intellectuals," in Intellectuals and Tradition, ed. S. N. Eisenstadt and S. R. Graubard (New York: Humanities Press, 1973), 76. For a study of this type of linguistic borrowings, neologisms, and loanwords, and of their significance for the formation of China's modern consciousness, see Lydia Liu, Translingual Practice: Literature, National Culture, and Translated Modernity-China, 1900-1937 (Stanford, Calif.: Stanford University Press, 1995).

33. Quoted in Schwartz, "The Limits of 'Tradition Versus Modernity' as Categories of Explanation," 81. 
ing," ${ }^{34}$ the idea of the West, understood and presented much as a monolithic and homogeneous entity, afforded the May Fourth intellectuals an enabling category, with which Chinese "tradition" and indigenous systems of knowledge could be conveniently compared historically, morally, and culturally. It would be wide off the mark, therefore, to consider such comparisons between the West and China, between the modern and the traditional, merely as intellectual or academic issues. In its historical context, the strategic appropriation of the binary oppositions of this kind performed a unique function in generating and reinforcing the national sense of great urgency that radical social reforms were needed to reinvent China, although this should not lead to the conclusion that the May Fourth intellectuals had a common notion of modernity and that "tradition" - whatever it may be-was thoroughly decomposed in actuality.

\section{The Politics of Criticism}

It is in relation to this May Fourth reform project that the new literary movement, as part of what Chow Tse-Tsung calls the "intellectual revolution," helped to shape and define China's modern consciousness. "Literature," Chow observes, "was the major profession of the traditional Chinese intellectuals. This fact immediately explains why the literary revolution played so significant a role in the May Fourth Movement, which was led by the intelligentsia." ${ }^{35}$ However, while there have been copious studies of the significance of the new literary movement-in particular, in relation to forms of creative writing, such as new fiction and new poetry-little attention has been given to the rise of modern criticism and to its significant contribution to the May Fourth cultural movement. Discursive critical production at the time, massive in quantity, is often seen as a means rather than a formation in itself, and as such it has always been placed in the shadow of the achievements of the new literary revolution, which, ironically, it inspired, promoted, supported, and guided. Part of the irony, indeed, is that most of those May Fourth critics had several intellectual or literary personae, and they were not only critics but also poets or novelists or scholars as well and have been registered as such rather than as critics in Chinese literary histo-

34. Roland Barthes, Empire of Signs, trans. Richard Howard (New York: Hill and Wang, 1982), 4.

35. Chow Tse-Tsung, The May 4th Movement, 269. 
riography. The function of modern criticism is repressed, and its significant contribution to the literary revolution during the May Fourth period is overlooked and neglected, partly because of the practice of a methodological rigidity in literary scholarship in China that tends to impose a stringent classification of authors into groups or categories previously established.

In historical retrospect, however, it is impossible to imagine the literary revolution in the absence of discursive critical practice during the May Fourth period. In a sense, the new literary movement, and for that matter, the May Fourth new cultural movement as a whole, was, above all, a critical movement. It is in the practice of criticism that the earlier intellectual and political radicalism was significantly sustained, visibly concentrated, and forcefully rearticulated. Liang Qichao, as is well known, had vigorously argued in his critical writing for the importance of reforming Chinese literary tradition in the process of modernizing the Chinese nation. For him, literature was the pulse of the body politic, and constituting the centrality of the modern novel as a replacement for traditional Chinese fiction, for example, was essential for the creation of China's modern consciousness. ${ }^{36}$ Although the rise of modern criticism and its tremendous importance in China in the first few decades of the twentieth century have not yet received enough scholarly attention, some literary practitioners at the time recognized its significance in promoting new forms of literary production. Mao Dun, for example, wrote in 1921: "Criticism in literature has helped to bring about the flourishing of Western literature. It has great authority and shapes the thoughts of art and literature in a period.... There has never been any criticism in our country. 'There must be first the critic before the real writer'this is one of our firm beliefs. We are not bright, therefore we first introduce Western criticism and use it as our guide." ${ }^{37}$

The rise of modern criticism in the early twentieth century was a collective response to the conditions of China at the time and a manifestation of the desire to engage directly with cultural and social issues. In terms of both its objective and its way of circulation, modern Chinese criticism was no longer confined to the poetic and aesthetic or practiced within a small social

36. Liang wrote in 1902: "If one intends to renovate the people of a nation, one must first renovate its fiction." See Liang Qichao, "On the Relationship between Fiction and the Government of the People," in Modern Chinese Literary Thought: Writings on Literature, 18931945, ed. Kirk A. Denton (Stanford, Calif.: Stanford University Press, 1996), 74.

37. Mao Dun, "Xiaoshu yuebao gaige xuanyan" (Manifesto for reforming Fiction Monthly), in Mao Dun wenyi zalun ji (Mao Dun's miscellaneous essays on art and literature) (Shanghai: Shanghai wenyi chubanshe, 1981), 1:20. 
elite, as shihua had been. Modern Chinese criticism was defined, from its incipient stage, by its awareness of the importance of active social intervention, its distinct and visible social presence as a significant formation and agency. Like their early Western counterparts in the eighteenth century, the May Fourth critics became public critics, and they collectively responded to, and at the same time created, what Bourdieu calls, in a different context, "the historical and social conditions of possibility," ${ }^{38}$ under which the idea of literary modernity was converted into a national project in the sphere of public experience.

Hu Shi, for example, published, in 1907, his famous manifesto of the new literary movement, "Some Tentative Suggestions for the Reform of Chinese Literature," in which he called for a new literary practice. Referring to what he saw as the defects of traditional literary production, Hu prescribed eight principles for a new literature: (1) Nothing is said without substance; (2) Don't imitate the ancient; (3) Pay attention to grammar; (4) Don't produce soppy writings; (5) Get rid of stale and archaic diction; (6) Never use allusions; (7) Don't use syntactic parallelisms; (8) Don't avoid using common language ${ }^{39}$ In providing this set of dicta, Hu envisaged new forms of literary production that, according to him, were unknown in China. Reflecting on this manifesto a year later, Hu said that the methods of Western literary production were far superior, and that in China there were no equivalents of such forms of writing as Plato's philosophy, Thomas Henry Huxley's scientific writing, James Boswell's biography, or Mill's and Benjamin Franklin's autobiographies. They, claimed Hu, "were never even dreamed of in China." ${ }^{40}$ We may add to Hu's list the kind of modern critical writing produced by such people as Addison. It is not our purpose here to valorize Hu's proposal, to argue for or against it. What is pertinent for us is that his vision of a new literary experience was underscored with an intellectual and political agenda that aimed at mobilizing and rallying public support for the reformation of Chinese literary tradition, and of Chinese society, for that matter. Drawing heavily on Western post-Enlightenment thinking and systems of knowledge on the one hand, and Chinese folk cultural and literary production on the

38. Bourdieu, The Rules of Art, 286; original emphasis.

39. Hu Shi, "Wenxue gailiang chuyi" (Some tentative suggestions for the reform of Chinese literature), in Hu Shi xueshu wenji: Xinwenxue yundong (Collection of Hu Shi's academic writing: The new literary revolution), ed. Shen Ji (Beijing: Zhonghua shuju, 1993), 20. See also Chow, The May 4th Movement, chap. 11, "The Literary Revolution," 269-88. 40. Hu Shi, "Jianshe de wenxue geming lun" (On the constructive literary revolution), in Collection of Hu Shi's Academic Writing, 53. 
other, Hu Shi was engaged in a project to subvert the hegemonic discourse of classical literary formations by promoting the common taste and advocating the democratization of literary experience.

Hu's critical writings, like those by other leading May Fourth cultural critics, such as Chen Duxiu and Lu Xun, appeared mostly in periodicals of mass circulation. At the same time, a large number of modern forms of information dissemination-newspapers, magazines, and periodicals-came into being, opened up new avenues for engaging with public issues, and further consolidated this relatively autonomous critical space, in which critical intellectuals, enabled by these new forms of publication and circulation, were able to reach out to the public. ${ }^{41}$ New Youth, a leading journal of critical scholarship at the time, for example, became the bastion of radical intellectuals.

Habermas's notion of the public sphere is innately related to the bourgeois social formation and the development of civil society. Chinese society in the early twentieth century was not in any sense a civil society, and there was no educated middle class or bourgeoisie to serve as a major social and political force. However, in the absence of the political structure of civil society and the social force of an established middle class, it may be argued that there existed at the time a public sphere, perhaps not as a classspecific category but as an intellectual formation determined by the political and social conditions of China. The republican revolution in 1911 that expelled China's last emperor from the Forbidden City did not result in the establishment of a strong central government. The absence of a state authority conspicuously left open a social space in which intellectuals, generally speaking, were able not only to freely debate and express but also to shape public opinion and therefore influence the course of social development. The public sphere, for Habermas, is, above all, one that is formed by "private people" coming together as a public in opposition to the public au-

41. For a discussion of the formation of the public sphere in China in relation to the mass media, see Leo Lee, “'Piping kongjian' de kaichuang” (The establishment of a "critical space"); and for a case study of Chinese modern publishing business, see Meng Yue, "Shangwu yinshuguan chuangbanren yu Shanghai jindai yinshuawenhua de shehui goucheng" (Founders of the Commercial Press and the social formation of Shanghai's modern printing culture). Both are included in Piping kongjian de kaichuang: Ershishiji zhongguo wenxue yanjiu (The establishment of critical space: Studies in twentieth-century Chinese literature), ed. Wang Xiaoming (Shanghai: Dongfang chuban zhongxin, 1998), 101-17 and $81-100$, respectively. 
thority. ${ }^{42}$ In China, the public authority these "private people" opposed was not exactly a political establishment or a state authority but what they saw and understood as a cultural hegemony-Chinese tradition, whether real or imagined-which was built on the constituted indigenous systems of knowledge. This liberal intellectual sphere was occupied and pushed out collectively by public critics and writers during the time and found clearest expression in the massive amount of critical writing produced within a relatively short time. Modern criticism became a public practice precisely because of the establishment of this public sphere, which, together with the advent of modern modes of information/knowledge circulation, was a decisive factor in bringing into being the modern critical subject.

Energized by this critical movement and public support, the May Fourth intellectual revolution was astonishingly successful. In the domain of literature, for example, new forms of production, such as the modern novel, vers libre, and modern drama, were soon to inhabit permanently the Chinese literary landscape, replacing the classical mode of storytelling, shi/ci poetry, and traditional forms of dramatic production. Various Western literary styles and techniques, such as realism, romanticism, symbolism, impressionism, and imagism were brought into China and ushered in an extraordinarily productive period in the modern history of Chinese literature. At the same time, modern scholarship started to take shape and would further develop into modern academic disciplines. ${ }^{43}$ Perhaps more significant is the success of the language reform movement, which, as a vitally important part of the cultural movement, established the modern vernacular as lingua franca in China. ${ }^{44}$ This historical change in the linguistic domain, from an old system of linguistic expression to a new one, marks the establishment of

42. See Habermas, The Structural Transformation of the Public Sphere, 27.

43. Chen Pingyuan asserts that modern Chinese scholarship was instituted following, among other things, the subversion of the centrality of Confucian classics and Confucianism, the advocation of Enlightenment values, the acceptance of modern scientific research methodology, and the classification of knowledge into academic disciplines in the late nineteenth and early twentieth centuries. See Chen Pingyuan, Zhongguo xiandai xueshu zhi jianli (The establishment of modern Chinese scholarship) (Beijing: Beijing University Press, 1998), 9.

44. For a discussion of how the language reform movement was inspired and influenced by Western missionaries' efforts to alphabetize written Chinese characters and, more generally, by Orientalist views on the Chinese language, see Q.S. Tong, "Inventing China: The Use of Orientalist Views on the Chinese Language," Interventions: International Journal of Postcolonial Studies 2, no. 1 (2000): 6-20. 
the linguistic modernity, the significance of which cannot be sufficiently emphasized. The idea of Chinese modernity as a general category can thus be historicized and given specific meanings by some of these new discursive cultural formations.

Modernity, or, rather, the Western notion of modernity, is not just an idea or ideal; it can readily be turned into a social practice that knows no geographical or cultural boundaries. And the notion of literary and critical modernity is intertwined with the idea of social and political modernity in China. It is notable that after the establishment of modern criticism in China in the early twentieth century, most critical practitioners were unable to disengage themselves from political concerns. If critical debate in the West in the eighteenth century, as Habermas observes, "was soon extended to include economic and political disputes, without any guarantee ... that such discussions would be inconsequential, at least in the immediate context," 45 modern Chinese criticism was born a political practice, and its practice had significant consequences. In the 1930s, left-wing critics, assembling in the critical space of Shanghai, saw criticism as an energizing force that was instrumental for the Communist revolutionary cause. Mao Zedong, in 1942, surprisingly acted as a literary critic and, in defining his notion of revolutionary literature in his famous "Talks at the Yan'an Forum on Art and Literature," stretched the political and public function of literature to the breaking point. It would require a separate study to deal with the conversion of criticism into a totally political discourse in China, but let us note here that precisely because modern criticism, especially after Mao's "Talks," has been so intimately intertwined with politics in China, the practice of criticism, perhaps more than any other form of literary practice, is seriously consequential in social and political terms. The inseparability of criticism and politics in China was tragically and compellingly manifested in the case of Hu Feng, who, largely for his dissenting critical views, was jailed for over twenty years and suffered thereafter from a serious mental disorder, which had developed during his imprisonment. ${ }^{46}$

In the early twentieth century, the rise of modern criticism, concur-

45. Habermas, The Structural Transformation of the Public Sphere, 32.

46. Hu Feng (1902-1985), a Marxist critic and disciple of Lu Xun in the 1930s, served two prison terms between 1955 and 1979 for his literary activities before 1949 and for his dissenting critical views. He attempted suicide in prison. In total despair, his mental health eroded in the late phase of his imprisonment. For a study of his critical theory, see Kirk Denton, The Problematic of Self in Modern Chinese Literature: Hu Feng and Lu Ling (Stanford, Calif.: Stanford University Press, 1998). 
rent with the collapse of the classical critical establishment, was a collective response to the social and cultural conditions of China. As a discursive part of the May Fourth Enlightenment project, modern critical practice from its incipient stage was committed to and responsible for engaging with immediate social and political issues, until it sank into an overtly political discourse after the mid-twentieth century. This trajectory of modern criticism as a historical product illustrates its own logic of development. With this in mind, we may now return briefly to those calls for the inventing and constituting of a system of critical theory that bears distinct "Chinese" features. These calls, it is obvious, derive much of their intellectual energy from historical forms of critical knowledge, such as shihua. However, as we have attempted to show, the disappearance of shihua and, for that matter, traditional critical discourse as a whole, of which shihua is the most representative, is hardly a historical accident. The social and cultural conditions of possibility for the classical mode of critical practice no longer exist and cannot be revived. The desire to reconstitute a system of indigenous critical theory under the present condition, regardless of its nationalistic subtext, reminds us of all the anxieties, uncertainties, ambivalence, and frustrations that Wang Guowei and other literary intellectuals experienced in the early twentieth century. As soon as one seriously contemplates the possibility of creating a new system of critical knowledge with "Chinese" features, one is necessarily faced with such questions as: Which "Chinese features" would be included in this system of critical theory? How would this new system position itself in relation to the May Fourth tradition of critical practice? What would be the relationship between it and classical criticism? How should it negotiate synchronically with theoretical developments outside China?

No doubt, in the foreseeable future, at least, the desire to construct a Chinese critical theory will continue to generate intellectual imaginaries and political anxieties. By asking these questions, however, we seem to have completed a historical cycle. We seem, that is, to have returned to the spot where Wang Guowei started. Wang's "On A Dream of the Red Chamber" and Talks on Ci Poetry in the Human World, produced within the time frame of four years, constitute only a fraction of his critical and scholarly output. They illustrate, however, his virtuosity in Chinese critical language and, at the same time, his recognition of the potential of Western critical knowledge when applied to readings of Chinese literary production. Informed and inspired by both the indigenous system of critical practice and Western-in particular, German - aesthetic theory, Wang's critical work is an amalgamation of differing and sometimes warring critical approaches, theoretical posi- 
tions, and intellectual agendas, an amalgamation that, for us, epitomizes the very cultural conditions of China in the late nineteenth and early twentieth centuries. His suicide may be an isolated incident. However, viewed in its historical context, Wang's death is not just a personal tragedy but a national allegory of the fate of the indigenous critical system, an allegory that seems to have a freshly renewed relevance to the present cultural conditions of China. 